\title{
A. MARVIN SHEW, M.D.
}

To any one who has visited the Hospital for the Insane at Middletown, Connecticut, during the period 1868-86, it must have been melancholy news to hear that so able, upright, and humane a superintendent had passed away. Regrettable under any circumstances, the regret is heightened from the circumstance that the end came in consequence of an accident. Dr. Shew fell on the stairs of the hospital, the result being injary to the spine, and, in the course of some weeks of suffering, apoplexy. Dr. Shew was born in 1841 at Le Ray, Jefferson County, New York. We recall a family incident which he told us when visiting the asylum in 1884, namely, that his father, a German, made a voyage to the United States, intending merely to visit the country, but during a violent storm, in which the vessel was in great danger, he solemnly vowed that if he ever reached land he would never return to Germany. Shew received his academic education at the Jefferson County Institute, and, having ohosen the medical profession, and studied under Dr. Bates of Waterton, he became a medical officer in the Asylum for Insane Convicts at Auburn, where he resided a year before his graduation in 1864 at the Jefferson College. During the war he was in the army for fourteen months in a medical capacity. Subsequently he was one of the resident physicians at the Blockley Hospital at Philadelphia. In the spring of 1866 he was elected aseistant medical officer in the New Jersey State Lunatic Asylum, Trenton, of which Dr. Buttolph was the super. intendent.

When the Legislature of Connectiont chartered a hospital for the insane, Miss Dix named him to the trustees as well fitted to organise and take charge of the institution, and on the 15th of October, 1866, he was appointed medical superintendent. "It was a responsible and difficult work," says the "Memorial," from which we have obtained the particulars of Dr. Shew's life, " enough to tax the wisdom and strength of a much older man. Bat his wide experience in hospital and army life, his quickness of perception and maturity of judgment, his remarkable faonlty of presenting his own views so as to win the ussent and co-operation of others, and his singleness of purpose fitted him for the emergency. He had the hospital in readiness to receive patients in the spring of 1868. His devotion to his work after a few years serionsly impaired his health, but it won for him the affectionate regard of his assistants and of those who were daily associated with him, and the confidence of the good people of Connectiont; also the profound respect of the foremost men of the State, with whom his duties brought him in contact; of the members of the legal profession who had occasion to consult him as an expert in cases of insanity, and not less of a wide circle of the members of the medical profession who enjoyed his acquaintance. He was ready with his pen to con. tribute to the medical journals, to the Association of Superintendents of Hospitals for the Insane, and not less to the literary and scientifio associations to which he belonged in Middletown. His annual reports of the hospital were uniformly interesting and valuable. He was not satisfied with what had been done, but ever said that improvements might be made. He was not content with veneer or mediocrity in building or administration."

The particular service rendered by $\mathrm{Dr}$. Shew in hospital management consisted in his providing separate buildings and cottages in the establishment, adapted for the different classes of cases which must always exist in asylums for the insane. Besides the enlargement of the main bailding, two additional ones, each capable of accommodating from 250 to 300 patients, were erected, the last being completed a little before his death. He had 1,100 patiente under his care, with room for 150 more. 
Dr. Pliny Earle (Northampton, Mass.), in a letter to us, thus writes:- "The characterization of Dr. Shew in the 'Memorial' is no exaggeration, but is truthfal and just. He was a worthy, meritorious man, a genial friend, to whom I was sincerely attached, and whose loss I as sincerely mourn."

\section{Correspondence.}

To THE IEDitors or THE Journal of Mental Science.

Grintumen, - In the following remarks, I wish to be animated with a humble spirit; and, if I state anything strongly, I am conscions that I aim at moderation in my sentiments. I would be lacking in the bare and comparatively beggarly elements and first principles of Christian feeling, if I entertained for $a$ moment the idea of unfriendliness on the part of asylum officials, or donbted that the least amiable of them had any desire but the welfare of such as are committed to their charge. It cannot be expected that the laws which govern society as a whole are altogether applicable in asylums. The ruling and guiding principle, the mind, being more or less morbidly affected in the insane - to anticipate that laws will have the same force with them as with those possessed of mental health, is like expecting fine music from a broken instrument or from one that is entirely out of tune. Regard will be paid to this in all well-regulated asylums. It will ever be uppermost in the thoughts of the officials that those amongst whom they mingle are not like themselves able to control their actions ; since they are not, as in the case of sane persons, actuated by ordinary motives, or similarly influenced by outward circumstances. If a man's will is so over-borne, and his power of selfcontrol so over-mastered, that he acts in a manner that lays him open to censure-is be to be blamed and punished ? If a man suffers from temporary aberration of intellect daring a paroxysm, he is not responsible. He feels, on recalling any particular action he may have done during illness, that he could not hare done otherwise; for his reason-such as it was, defective and weakened as it must then have been-approved: though admittedly it was this power of the mind, pressed and harassed by the force of emotion and passion, that pronounced the rerdict. The nature and consequences of his action were not for a moment thought of. If quite well, he would certainly have acted otherwise in the same circumstances: bat the question ariseswonld the same convention of circumstances ever occur in a state of mental health, or during a period of convalescence? Were the element of punish. ment eliminated from the asylum treatment, it might be asked-how are order and discipline to be maintained ? We know how much the non-restraint gystem was at first opposed. We know how very gradually, as a rule, ameliorating influences are allowed to have their due weight upon society of all kinds. In the minds of Tuke, Hill, and Conolly, the removal of restraints implied that in the treatment of the insane nothing should be present which has a tendency to thwart or irritate. There is a lingering aversion among some alienist physicians to cast from them the idea that wickedness is an element in the conduct of the insane which necessarily presupposes responsibility. If this stumbling-block were removed, the object $I$ aim at would be more easily attained. It is certain that in many cases insanity is owing to accident or misfortane, and not to sin; and in judging of other cases, it is 